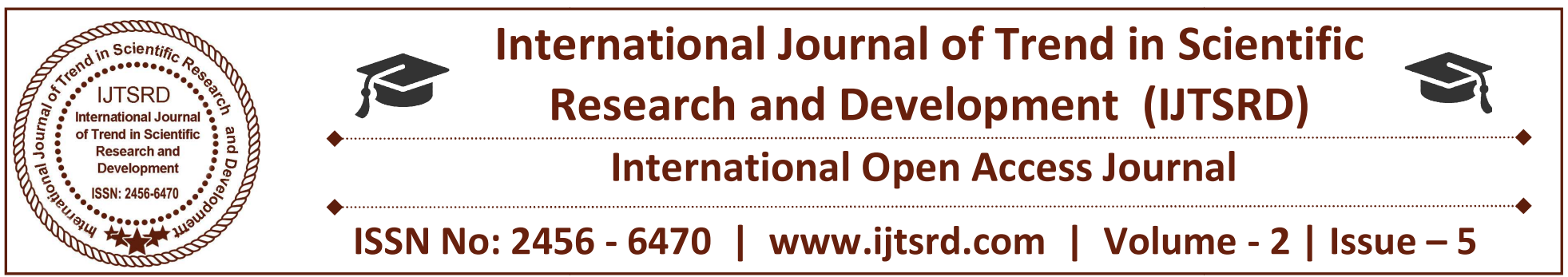

\title{
Juvenile Delinquency- Victimization or Criminalisation
}

\author{
Vidisha Varun \\ B.B.A., LL.B (Hons), Indore Institute of Law \\ Indore, Madhya Pradesh, India
}

\section{ABSTRACT}

The literal meaning of juvenile delinquency is not so wide as its symbolic meaning. The implicit concept is to be studied relatively as "Victimization" or "Criminalisation". It could be observed that the root causes of the offences committed by a child or juvenile are actually committed whether mostly out of malice, ie., criminal intention or due to the forcibility by poverty, starvation and other social evils. A child or juvenile is considered as vulnerable and delicate being of the society. This study can dig out the reasons why and how young minds start to walk on the track of being delinquent. This can sketch out their way from becoming unnourished and needy because of widespread pauperism to their conversion into an offender. Although it has been a known fact that the word "misconduct" means pre-planned offence with guilty mind but in case of child or juvenile it cannot be said firmly. As children move into puberty, they become increasingly autonomous and spend a greater proportion of their waking hours with nobles outside the home. At the same time, their risks of victimization increase substantially. Although in-home violence and child abuse are important forms of juvenile victimization, other entries in this volume discuss these forms of abuse in depth. Accordingly, the focus here is primarily on non-familial victimization - the kind that occurs outside the home, in school, and on the streets.

\section{INTRODUCTION}

\section{A Prologue-}

Juvenile is considered as a child who has not completed a specific age as mentioned in the law of any country and doesn't bear resemblance as an adult person and who can be made legally answerable for his criminal activities. The juvenile is a child who has alleged violated certain laws which declares his act or omission as an offence. A juvenile and a minor are used in different perspective in legal terms. The term juvenile is generally used in reference to a young criminal offender and minor is related to legal capacity of a person.

\subsection{Research Objective-}

This research aims to the overall study on juvenile delinquency and its nature. It consists of the broad statements of desired outcomes and the general intentions of the research.

\subsection{Research Methodology-}

The researcher has used both primary and secondary sources. The data has been collected from online sources, magazines, journals, reference books etc.

\subsection{Research Questions-}

1. What is meant by juvenile delinquency?

2. What are the situations in which a child commits crime?

3. What is the extension of the criminal psychology of people under 18 ?

4. What are the reasons behind juvenile victimization by being delinquent?

5. What are the differences between Victimization and Criminalisation and how an offence by a child makes it relatable?

\section{WHAT IS MEANT BY JUVENILE DELINQUENCY?}

The word "juvenile" means child offenders and the word "delinquency" means misconduct. Juvenile delinquency is the participation by a minor child, 
usually between the ages of 10 and 17, in illegal behaviour. Juvenile delinquency is also used to refer to children who unveil a persistent behaviour of animosity or disobedience, so as to be considered out of parental control, becomes subject to legal action by the court. Juvenile delinquency is also known as "juvenile offending," and each state has a separate legal system in place to deal with juveniles who break the law. Juvenile delinquency occurs when a minor behaves like a criminal character. When a juvenile commits a crime, the procedures that take place differ from those of an adult offender. In all states, juvenile court systems deal definitely with underage offenders. Definition of delinquency includes "act and conduct which violates the law only when it committed by children". The legal definition of Juvenile Delinquency is "any act prohibited by law for children up to prescribed age limit is Juvenile Delinquency". 1

\section{$\underline{\text { Age-Specific Offenders }}$}

This type of juvenile delinquent behaviour begins during puberty. Unlike the repeat offenders however, the behaviours of the age-specific offender ends before the minor becomes an adult. The conducts that a juvenile shows during adolescence are often a good indicator of the type of offender he will become. While age-specific offenders leave their delinquent conduct behind when they enter majority, they often have more mental health problems, engage/ in substance abuse, and have greater financial problems than adults who were never delinquent as juveniles. Delinquency is unwelcomed action, omission or moral behaviour of a juvenile which is socially not permitted in any society. Generally it means that if the child fails to meet certain social obligations predicted from them by the people, then he is considered to be delinquent. The juvenile delinquent is behavioural disorder which is generally defined as "a child pretending to act like a grown up or adult". The action of the child can be seen as a innocent imprudent behaviour but it can also cause serious fear and concern. There is a very distorted distinction between a delinquent child and a normal child and his behaviour to anxious person is the deciding factor among a cheerful act and delinquency. Generally there is a haze of ambiguity surrounding delinquency

\footnotetext{
${ }^{1}$ Juvenile crime, juvenile justice, 2001, The National Acadamies Press (7 july, 2018, 2:05 pm),

https://www.nap.edu/read/9747/chapter/3.
}

and there is no single general acceptable definition for it. $^{2}$

\section{WHAT ARE THE SITUATIONS IN WHICH A CHILD COMMITS CRIME?}

The direct root cause of the offence committed by a child or juvenile is by being provoked due to social evils. The need to keep their existence in the society, force them to get involved into criminal activities. They are starved of the basic amenities of life.

\section{Family:}

Family is the basic socialization assistance for the children. Children learn basic concepts about good and bad from their family. They make their values and set the norms of society. Family can make or break the personality of the children. Most of the teen-agers who show delinquent behaviour in any form belong to families that could not give firm foundation to the children. Broken families, single parent families, separated families, frequent parents fight, lack of trust and self-control among the parents, criminal parents or psychosomatic problems in parents can be the most important reason behind juvenile delinquency. ${ }^{3}$

\section{Economic problems}

Often the cause of juvenile delinquency is economic problems in family. Youth belonging from poor economical position easily get elaborate in criminal activities. They want to improve their status and for this purpose they use harmful path, in this regard often people do not support teenagers who belong from poor status and they go for criminal activities. ${ }^{4}$

\section{$\underline{\text { Psychological problems }}$}

Psychological problems in parents or siblings can also be a risk factor of juvenile delinquency. Mental illnesses or other psychological problems like depression, frustration, aggression or hyper behaviour

\footnotetext{
${ }^{2}$ National Institute of Justice, office of justice programs (7 july, 2018, 4:48 pm),

https://www.nij.gov/topics/crime/Pages/delinquency-to-adultoffending.aspx

${ }^{3}$ Juvenile delinquency- what makes teens commit crime, secure teen, (9 july, 4:07 pm) https://www.secureteen.com/juveniledelinquency/juvenile-delinquency-what-makes-teens-commitcrimes/

${ }^{4}$ Juvenile delinquency- what makes teens commit crime, secure teen, (9 july, 5:02 pm) https://www.secureteen.com/juveniledelinquency/juvenile-delinquency-what-makes-teens-commitcrimes/
} 
showed by the parents can make the child feel deprived and inferior among friends. Sometimes children embrace depression and anger from parents or elder siblings. ${ }^{5}$

\section{$\underline{\text { Social problems in family }}$}

In many families parents or elder siblings are involved in various social problems. There can be various problems like gender discrimination, age discrimination, racial discrimination, child labour. Children and youth learn what they see in their family, in many rich families parents do not feel shame in child labour and children could not understand that child labour is against society and against morality. Social problems cause stress and due to stress youngsters get involved in violence. ${ }^{6}$

\section{Moral problems in family}

Morality is the most important concern among teens today. Adolescents should know how to respect family and other people. They should give the due respect to everyone they know and meet. Some parents do not take care of their elders, and it is a known fact that such children who see their parents disrespecting their elders, their children never respect their parents and elder siblings. ${ }^{7}$

\section{$\underline{\text { Parenting style }}$}

Parenting style also matters and many researchers say that it is one of the prime reason why teens commit crime. Parents are sometimes very harsh and they punish their children for small issues. Children start disrespecting their parents and they become violent. ${ }^{8}$

\section{Other Reasons-}

$\underline{\text { Social concerns }}$

\footnotetext{
5 Juvenile delinquency- what makes teens commit crime, secure teen, (9 july, 5:54 pm) https://www.secureteen.com/juveniledelinquency/juvenile-delinquency-what-makes-teens-commitcrimes/

${ }^{6}$ Juvenile delinquency- what makes teens commit crime, secure teen, (9 july, 6:00 pm) https://www.secureteen.com/juveniledelinquency/juvenile-delinquency-what-makes-teens-commitcrimes/

${ }^{7}$ Juvenile delinquency- what makes teens commit crime, secure teen, (9 july, 6:29 pm) https://www.secureteen.com/juveniledelinquency/juvenile-delinquency-what-makes-teens-commitcrimes/

${ }^{8}$ Juvenile delinquency- what makes teens commit crime, secure teen, (9 july, 6:50 pm) https://www.secureteen.com/juveniledelinquency/juvenile-delinquency-what-makes-teens-commitcrimes/
}

Teenage boys and girls go through several social problems when they are not well socialized human beings. Some teens are very harsh and rude to talk and they cannot control their anger or aggression as it is in their nature. Most of the gender biased boys talk to the opposite sex like they are slaves and they do not respect them. Their violence and aggression make them commit crimes that other boys will never do. ${ }^{9}$

\section{Psychological concerns}

Psychological and mental concerns are also important when talking about juvenile delinquency. Mental disability is another big cause of juvenile delinquency. Mentally ill boys or girls can commit any crime without knowing the consequences of it. ${ }^{10}$

\section{Drug use}

Drug use has become widespread among teenage boys and girls. Drugs use is prohibited by laws in many societies. Drug use in youth can be dangerous as they can commit violent crimes when they take drugs.

\section{Poverty and Education}

There are undoubtedly many factors contributing to juvenile crime, but the focus should be on those which contribute the most. The two factors which come most readily to mind are the extremes of poverty and poor education. Juveniles from poor communities are not even interested in becoming educated because there are not any decent paying jobs for them anyway. By not going to school, these juveniles are not are not developing the proper mental context with which they can make good choices in life. The growing numbers of poor communities does not help the situation. The biggest differences between the upper-class and lower-class communities is the quality of education the youths receive and economic security. In upperclass communities juvenile crime exists, but it is far less common and severe than in the impoverished communities. Neighbourhoods with a high concentration of poverty are at a much higher risk of having problems such as single-parent families, ineffective parenting, violent schools, high dropout

\footnotetext{
${ }^{9}$ Juvenile delinquency- what makes teens commit crime, secure teen, (9 july, 7:04 pm) https://www.secureteen.com/juveniledelinquency/juvenile-delinquency-what-makes-teens-commitcrimes/

${ }^{10}$ Juvenile delinquency- what makes teens commit crime, secure teen, (9 july, 7:17 pm) https://www.secureteen.com/juveniledelinquency/juvenile-delinquency-what-makes-teens-commitcrimes/
} 
rates, substance abuse, and high unemployment rates. Youths growing up in such an environment are experiencing violence daily and are destined to resort to violence themselves. Poor communities have a tendency to be very unstable because of economic insecurity. Economic insecurity is caused by chronic unemployment. This is especially a problem in the inner-cities where, without jobs, people live impoverished and overcrowded lives. Since they are not able to sell their labour, they choice to illegitimate fairs such as drugs and prostitution. The illegitimate businesses emerge because the communities cannot effectively resist them. ${ }^{11}$

Unemployment is not the source of frustration and desperation that eventually leads to violence. A lack of income is, because it forces people into situations that they would choose not to be in. Robbery, prostitution, and drug dealing yield practical and immediate results. These industries naturally organize into street gangs which are known for their violent behaviour. If these people were properly educated and lived in an economically secure environment, then there would not be any reasons for them to engage in crime. $^{12}$

\section{WHAT IS THE EXTENSION OF CRIMINAL PSYCHOLOGY OF PEOPLE UNDER 18?}

As to the extent of the factors which affects the child's commission of the act. The findings showed us that the most prominent internal factor that affects a child delinquent act is due to home environment followed by parental relationship and some are due to sibling failed relationship. The result is in consonance with several studies which proved that familial characteristics suggesting familial antisocial behaviour or values such as family history of criminal behaviour, harsh parental discipline, and family conflict have been among the most consistently linked. Indeed the very absence of intact families makes gang membership more appealing. Further details have supported these findings as World Youth report claimed that children who receive adequate parental supervision are less likely to engage in

\footnotetext{
${ }^{11}$ Juvenile delinquency- what makes teens commit crime, secure teen, (9 july, 7:56 pm) https://www.secureteen.com/juveniledelinquency/juvenile-delinquency-what-makes-teens-commitcrimes/

12 Juvenile delinquency- what makes teens commit crime, secure teen, (9 july, 7:44 pm) https://www.secureteen.com/juveniledelinquency/juvenile-delinquency-what-makes-teens-commitcrimes/
}

criminal activities. Dysfunctional family settingscharacterized by conflict, inadequate parental control, weak internal linkages and integration, and premature autonomy-are closely associated with juvenile delinquency. Children in disadvantaged families that have few opportunities for legitimate employment and face a higher risk of social exclusion are overrepresented among offenders. The plight of ethnic minorities and migrants, including displaced persons and refugees in certain parts of the world, is especially distressing. The countries in transition are facing particular challenges in this respect, with the associated insecurity and turmoil contributing to an increase in the numbers of children and juveniles neglected by their parents and suffering abuse and violence at home. ${ }^{13}$

On the other hand an external factor to be most influential seems to maintain the pressure with peers. World Youth Report supported this as membership in a delinquent gang, like membership in any other natural grouping, can be part of the process of becoming an adult. Through such primary associations, an individual acquires a sense of safety and security, develops knowledge of social interaction, and can demonstrate such qualities as loyalty or leadership. In "adult" society, factors such as social status, private welfare, race and ethnicity are of great value; however, all members of adolescent groups are essentially in an equal position and have similar opportunities for advancement in the hierarchical structure. In these groups well-being depends wholly on personal qualities such as strength, will and discipline. Quite often delinquent groups can counterbalance or compensate for the imperfections of family and school. Community rules play a major role in influencing the commission of delinquent activities among minors. To further support this findings asserted that the bad influence of a repeat juvenile offender exerts a strong force on kids nearby. The study's authors discovered a powerful correlation between the type of crime, or crime specialization, committed by the observed juvenile and the crimes chosen by their suddenly trouble-making neighbours. The same was true for drug crime and violent crime. Researchers believe this force of influence could be the reason certain areas become known for a particular type of crime. The phenomenon of crime specialization was especially strong when observing

\footnotetext{
${ }^{13}$ Juvenile offenders, criminal justice, (12 july, 6:45pm), http:/criminal-justice.iresearchnet.com/forensicpsychology/juvenile-offenders/
} 
drug offenses. Criminologists believe this is due to the relatively well-organized neighbourhood structure required for drug crime to thrive. Moreover, a strong positive association between internal and external factors was found out. As the internal factors contribute to the child delinquency it is more likely that the external factor also contribute to it. ${ }^{14}$

\section{WHAT IS THE RELATION BETWEEN VICTIMIZATION AND CRIMINALISATION?}

It is a widely voiced notion that juvenile delinquency and victimization co-occur extensively in the youth population, in particular because delinquent youth engage in risky activities. But theory from the bullying and traumatic stress words suggests that there may be additional pathways by which delinquency and victimization are connected. This analysis looks for possible subtypes of delinquents and victims consistent with such pathways. Using the Developmental Victimization Survey, a national sample of 1,000 youth aged 10 to 17 were interviewed over the phone. Support emerges for three distinct types of delinquent-victims, who are termed bullyvictims, delinquent sex, maltreatment- victims, and property delinquent-victims. There is also-evidence for substantial groups of youth who are primarily delinquent but not seriously victimized, as well as youth who are mostly victimized but not delinquent. The state of being victimized, provoke the juveniles to commit any criminal offence. And this can be said as the main relation between victimization $/$ and criminalisation. $^{15}$

\section{PRECEDENCE OF VICTIMIZATION-}

Children and youth are victims of theft and violent crimes. Some juveniles are victims of abuse and neglect at the hands of their parents or other caregivers. The term "dependent and neglected children" describes those who are not provided with proper shelter, clothing, food, clean and safe living situations, and medical needs. Child abuse ranges from verbal abuse to physical and sexual abuse. Child victimization has been related to problem behaviours, delinquency, and criminal behaviour later in life. An understanding of victimization and juvenile

\footnotetext{
${ }^{14}$ Juvenile offenders, criminal justice, (12 july, 6:57pm), http://criminal-justice.iresearchnet.com/forensicpsychology/juvenile-offenders/

${ }^{15}$ An international journal on evidence based research, policy and practice; victim and offenders, volume 13( 12 july, 4:36 pm) https:/www.tandfonline.com/doi/abs/10.1080/15564886.2017.13 83958
}

delinquency is, therefore, important for a better understanding of the most appropriate juvenile justice system responses to these problems. The term "dependent and neglected children" describes those who are not provided with proper shelter, clothing, food, clean and safe living conditions, and medical needs. Child abuse classes from verbal abuse to physical and sexual abuse. ${ }^{16}$

\section{TYPES OF JUVENILE DELINQUENCY:-}

There can be four types of delinquencies: (a) individual delinquency, (b) group-supported delinquency, (c) organised delinquency, and (d) situational delinquency.

(a) Individual delinquency:

This refers to delinquency in which only one individual is involved in committing a delinquent act and its cause is located within the individual delinquent.

This delinquency is caused by psychological problems declining primarily from defective, faulty, pathological family interaction patterns. They pandered in delinquency as a solution to these problems, as it (delinquency) either brought attention from parents or provided support from peers or reduced their guilt feelings.

\section{(b) Group-supported delinquency:}

In this type, delinquencies are committed in companionship with others and the cause is located not in the personality of the individual or in the delinquent's family but in the culture of the individual's home and neighbourhood. The main finding in understanding why the young became delinquent was their association and companionship with others already delinquent.

\section{(c) Organised delinquency:}

This type refers to delinquencies that are committed by formally organised groups. This concept refers to the set of values and norms that guide the behaviour of group members encourage the commission of delinquencies, award status on the basis of such acts

\footnotetext{
${ }^{16}$ An international journal on evidence based research, policy and practice; victim and offenders, volume 13( 12 july, 4:58 pm) https://www.tandfonline.com/doi/abs/10.1080/15564886.2017.13 83958
} 
and specify typical relationships to persons who fail outside the groupings governed by group norms.

(d) Situational delinquency:

The above-mentioned three types of delinquencies have one thing in common. In all of them, delinquency is viewed as having deep roots. In individual delinquency (according to the psychogenic explanation), the roots of delinquency lie primarily within the individual; in group-supported and organised delinquencies.

Situational delinquency provides a different perspective. Here the assumption is that delinquency is not deeply rooted, and motives for delinquency and means for controlling it are often relatively simple.

\section{RECOMMENDATIONS:-}

The study and treatment of juvenile victimization would profit from instruments that are broad, methodologically sound, and relevant to the aspects such as mental health clinics, criminal justice institutions, and child protection agencies. Among other things, instruments should (1) allow victimization to be mapped onto predictable crime and child protection system categories; (2) adequately consider victimization by family and other nonstranger offenders; (3) ask about crimes specific to childhood, such as nonviolent erotic offenses and neglect; (4) allow for comparisons between juvenile and adult victimizations; (5) collect self-report data with children as young as age 7 years; (6) behaviourally specific language; (7) protect privacy during data collection; (8) attend to possible ethnic, class, and gender differences; and (9) prepare procedures to support children in danger.

\section{CONCLUSION:-}

By this research study, it is observed that the juveniles are said to be vulnerable beings of the society and the direct root cause of the offence committed by a child or juvenile is by being provoked due to social evils which includes family problems, other social, psychological reasons. Other significant causes are poverty and lack of education. Lack of education results to unemployment and thus influence them to attract towards the delinquent behaviour. The victimization of the young is of great concern to researchers, practitioners, and policy makers. Juvenile victimization comes in many forms, and research has linked early victimization with numerous problems that persist throughout the life course. As children move into adolescence, they become increasingly autonomous and spend a greater proportion of their waking hours with peers outside the home. At the same time, their risks of victimization increase substantially. Although in-home violence and child abuse are important forms of juvenile victimization, other entries in this volume discuss these forms of maltreatment in depth.

(1)

